\title{
Thermo-mechanic and sensory properties of wheat and rye breads produced with varying concentration of the additive
}

\author{
Mirjana A. Demin ${ }^{1}$, Jovanka V. Popov-Raljić ${ }^{1}$, Jovanka G. Laličić-Petronijević ${ }^{1}$, Biljana B. Rabrenović ${ }^{1}$, \\ Bojana V. Filipčev², Olivera D. Šimurina² \\ ${ }^{1}$ University of Belgrade, Faculty of Agriculture, Belgrade, Serbia \\ ${ }^{2}$ University of Novi Sad, Institute of Food Technology, Novi Sad, Serbia
}

\begin{abstract}
The effects of different concentrations of complex additive containing emulsifiers, oxidoreductive substances and enzymes, on the rheological conditions of dough and sensory properties of three groups of bread were investigated. The dough obtained from mixed wheat and rye flours had the best initial quality and the lowest degree of protein network weakening. The best expected baking properties were shown by the white wheat flour due to the least damage of its starch. The use of the additive had an effect on the absorption of water and on the majority of $C$-values of all sorts of flour. The amount of additive had a significant effect on the sensory properties of wheat bread crumb texture. Also, storage duration significantly affected $(p<0.01)$ the sensory properties of integral wheat bread aroma-taste and the weighted mean score. The interaction of these two factors had no significant effect on any of sensory properties of the investigated groups of bread.
\end{abstract}

Keywords: wheat and rye bread, additive, Mixolab, sensory properties.

\section{SCIENTIFIC PAPER}

UDC 664.641.12/.14:66.022.3

Hem. Ind. 67 (3) 455-463 (2013)

doi: 10.2298/HEMIND120613091D

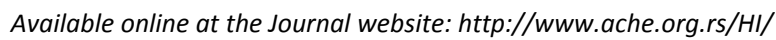

In the production of foods, as well as in the production of bread, a basic food product, the application of different additives is unavoidable. These additives are used deliberately, primarily for technological reasons, but also for nutritive or dietetic reasons, in any phase of their processing, storage or transportation, so that they become intrinsic components of the finished products [1]. Bread quantity introduced into the organism can vary. According to the Statistical Office [2], the average daily consumption of bread in Serbia amounts to about $300 \mathrm{~g}$. Because bread is consumed daily, quantities of additives and of other nutritive components are highly significant.

In practice, different additives are usually combined in order to profile the functional sensory properties and to ensure sensory and gastronomic acceptability of the specific product. Mixtures of additives, being the combinations of emulsifiers, oxido-reductive substances and enzymes (the so-called improvers) are of special importance for bakery products. Numerous investigations demonstrated the positive effects of these additives, and their formulation depends on a number of factors, between which the flour quality, kinds and quantities of other applied ingredients, the technological procedures, and the expected sort and quality of the finished products play the most important roles [1,3-5].

Correspondence: M.A. Demin, University of Belgrade, Faculty of Agriculture, Nemanjina 6, 11080 Belgrade, Serbia.

E-mail: demin@agrif.bg.ac.rs

Paper received: 13 June, 2012

Paper accepted: 10 August, 2012
Owing to their synergetic effects these additives influence the overall bread quality, which is reflected as the achievement of optimal rheological properties of dough, increase of dough development power and gas retention power, prevention of the microbiological deterioration, retention of the bakery products freshness, the improvement of sensory qualities of products such as increased volume and formation of the higherquality crumbs [6-9].

With the application of the empirical rheological methods it is possible to investigate the flour quality and to determine its suitability for the specific enduses, as well as to predict the final quality of the baked products $[10,11]$. The performances of traditional, empirical rheological methods for dough testing are timeconsuming [12] and do not provide complete information about the flour quality based on the characterization of all flour components, but only on the protein ratio and its quality, or on starch quality. The itemized analysis of these components is not sufficient, due to the interactions between them, as well as their interactions with other components of the flour such as enzymes, lipids, crude fibers, etc. All this plays a significant role in the overall flour quality and its processing characteristics [13].

In the course of dough processing, Mixolab ${ }^{\circledR}$ instrument measures physical parameters (water absorption, the development and stability of dough, protein network weakening (mechanical and thermal degradation) and the state of starch in dough (gelatinization level, amylolytic activity, cooking stability). These parameters highly correlate to the physico-chemical, classical rheo- 
logical [14] and the viscoelastic parameters, such as the gluten index, i.e. with the data obtained during the uniaxial and bi-axial extensions by Kiffer's apparatus and by the Rapid ViscoAnalyser $[15,16]$ that both enable predictions of the baking performances of flour and the quality of the finished product.

Being a foodstuff that rapidly changes (moisture loss, starch retrogradation, flavor loss) $[17,18]$, sensory evaluation of bread is one of the most efficient ways for following its properties that are considered to be one of the most significant characteristics with respect to defining the overall quality [19].

In the literature, a lot of data concerning the changes of bread sensory properties due to changes of the ingredients composition [20-23] processing conditions [24], storage temperature and [25] packaging procedures [26] can be found.

The most often found defects of bread quality include its volume diminishment, the textural crust and crumb changes (changes of the appearance - loss of brightness, crust structure changes - formation of the corrugations on the crust, structure changes of crumbs - brittleness and crumbing) $[24,27,28]$, as well as losses of taste and flavor [29].

The aim of this study was to investigate the effects of different concentrations $(0.1,0.3$ and $0.5 \%)$ of additive containing the mixture of enzymes, calcium phosphate, ascorbic acid and the emulsifier, on the rheological conditions of dough and on sensory properties of breads produced from the wheat flour T-500, the mixed wheat/integral wheat flour (50:50) and the mix from the wheat/integral rye flours $(40: 60)$ during the $0-3$ days of storage at $18-20{ }^{\circ} \mathrm{C}$.

\section{MATERIALS AND METHODS}

\section{Materials}

Commercial samples of white wheat flour T-500 (moisture content $12.7 \%$, mineral substances $0.58 \%$ d.b. and crude proteins $11.97 \%$ d.b.), integral wheat flour (moisture content 10.9\%, mineral substances $2.39 \%$ d.b. and crude proteins $13.08 \%$ d.b) and integral rye flour (moisture content $10.4 \%$, mineral substances $2.04 \%$ d.b. and crude proteins $9.57 \%$ d.b) were used for the bread manufacturing. Two sorts of wheat bread and one sort of rye bread with different concentrations of the additive XXL Aristo $(0.1,0.3$ and $0.5 \%$ on the flour basis) manufactured in semi industrial bakery conditions were used. Bread samples were categorized into three groups (Wheat Bread from $100 \%$ of wheat flour T-500; Integral Wheat Bread made from 50\% wheat flour and $50 \%$ integral wheat flour; Integral Rye Bread made from $40 \%$ wheat flour and $60 \%$ integral rye flour). The additive XXL Aristo (Backaldrin, Austria), a multipurpose improver, represents a complex mixture of enzymes, calcium phosphate (E-341), ascorbic acid (E-300) and emulsifier (E-472e).

\section{Basic flour composition}

Flour samples were analyzed by standard ICC (International Association for Cereal Science and Technology) methods for: moisture content [30], ash content [31] and crude proteins content [32]. The specific nitrogen to proteins conversion factor of 5.7 was used for the calculation of crude proteins content in flour. All analyses were performed in duplicate.

\section{Mixolab measurements}

Rheological estimations of the wheat flour T-500 and of mixtures of wheat flour T-500 with the integral wheat or rye flours (in the ratios and with the additive that was used during bread making), were performed by Mixolab ${ }^{\circledR}$ (Chopin Technologies, France) measures and plots in real time the torque (expressed in $\mathrm{Nm}$ ) produced by passage of dough between the two kneading arms [33] at constant temperature, as well as during the period of constant heating and cooling. The required amount of flour for analysis was calculated by Mixolab software according to input values of flour mixture moisture as well as water absorption. All the measurements were performed using the Mixolab Chopin+ protocol [34]. The protocol consisted of heating/cooling cycles after a certain mixing time at constant mixing speed: initial equilibrium at $30{ }^{\circ} \mathrm{C}$ for $8 \mathrm{~min}$, heating to $90{ }^{\circ} \mathrm{C}$ for $15 \mathrm{~min}$ (heating rate $4{ }^{\circ} \mathrm{C} / \mathrm{min}$ ), holding at $90{ }^{\circ} \mathrm{C}$ for $7 \mathrm{~min}$, cooling to $50{ }^{\circ} \mathrm{C}$ for $10 \mathrm{~min}$ at the rate of $4{ }^{\circ} \mathrm{C} / \mathrm{min}$ and holding at $50{ }^{\circ} \mathrm{C}$ for $5 \mathrm{~min}$; the mixing speed was kept at $80 \mathrm{rpm}$.

\section{Bread making process}

Breads, weighting $500 \mathrm{~g}$, were manufactured, using the named ingredients and with additions of $3 \%$ of yeasts and $2 \%$ of salt. The bread doughs were mixed and kneaded from 5 (white bread) to 20 min (integral wheat/rye bread) at room temperature and left to rise for 30-45 $\mathrm{min}$ before being divided into loaves. The loaves were left to prove at $30-35{ }^{\circ} \mathrm{C}$ for $45-60 \mathrm{~min}$ at relative humidity of $70-80 \%$. The loaves were baked in individual loaf tins at $200-220{ }^{\circ} \mathrm{C}$ for $25-30 \mathrm{~min}$ and then stored until sensory evaluation was performed.

\section{Sensory analysis}

Assessment of sensory characteristics of wheat and rye breads were carried out 6-8 $\mathrm{h}$ after baking and after $72 \mathrm{~h}$ of storage in a polypropylene foil (T19) at the ambient temperature $\left(18-20^{\circ} \mathrm{C}\right)$ by five trained panelists using the relevant ISO standards [35-39]. Sensory evaluations include the selected, representative, or dominant attributes of bread qualities: appearance (shape, crust color, nuance, brightness and uniformity), crust texture, crumb texture, aroma-odor of crust and crumb and aroma-taste of crust and crumb. The scores 
for each attribute ranged from 1 to 5 . With application of the weight coefficients [40], a quantitative expression of the total product quality was obtained as the "weighted" mean value of the scores for each of the evaluated parameter. Before performing the evaluations, it was important to determine weight coefficient for each property ( 4 for appearance, 4 for crust texture, 4 for crumb texture, 3 for aroma-odor of crust and crumb, 5 for aroma-taste of crust and crumb) and to balance them in such a way that their sum equaled 20. The sum of individual scores (each of them multiplied by respective weight coefficient) gave a complex indicator that represented the overall sensory quality expressed as "percent of maximum possible quality". Dividing this value by the sum of weight coefficients equal to 20 gave the weighted mean score, which also represented the overall sensory quality of samples.

\section{Quality category}

The quality categories were determined based on of score spans. Products that were evaluated with less than 2.5 points were considered as unsatisfactory, i.e., as unacceptable. Scores within limits of 2.5-3.5 characterized good quality, within 3.5-4.5 very good, and those within 4.5-5.0 excellent products. The volume of bread was expressed as specific volume $(\mathrm{ml} / \mathrm{g})$.

\section{Statistical analysis}

The obtained data was analyzed by descriptive and analytical statistics. The basic parameters of the descriptive statistics were arithmetic mean values, standard deviations $(S d)$ and variation coefficients $(C v)$. For analytical statistics (evaluation of sensory determinations data of breads), the two-factorial analysis of variance MANOVA was applied, with the first factor being the storage time (6-8 $\mathrm{h}$ after baking and after 72 $h$ of storage), and the second one - the composition of the evaluated bread samples (i.e., different concentrations of the additive), as well as the LSD-test (test of the least significant differences of pairs).

In order to fulfill the prerequisite for the application of the analysis of variance, homogeneity of variances was tested using Levene's test. For data that had homogeneous variance, based on the results of Levene's test, a parametric statistics was applied. In the case when variances were not homogeneous a parametric statistics was also applied, since the conducted (two) factorial experiment could not be analyzed by non-parametric statistics (Statistics V6 package) $[41,42]$.

\section{RESULTS AND DISCUSSION}

\section{Dough Torque Measurement Using Mixolab}

Mixing characteristics are strongly related to the dough rheological properties, and they can be recorded as torque vs. time curves obtained from small-scale mixers [43]. It is well known that the presence of biochemical constituents like added ingredients, additives, and technological aids in dough formulations, modifies the dough characteristics, affecting the baking performance $[44,45]$. Information concerning mechanical and thermal protein network weakening, starch gelatinization and starch gelling can be extracted from the curves recorded by Mixolab. The effect of the addition of different amounts $(0,0.1,0.3$ and $0.5 \%)$ of the additive on the dough rheological behavior of the different types of flours was also determined by the Mixolab (Figure 1). The purpose was to find out the differences in rheological behavior of dough obtained from pure wheat flour and from the mixtures with integral wheat or integral rye flours, as well as to find out the effects of different quantities of the additive on sensory properties of the finished fresh and stale bread.

Keeping in mind that there are few published data on the significance of parameters that can be obtained on the basis of Mixolab measurements, only general comments for the investigated samples could be given. With respect to the control sample without additives, the thermo-mechanic changes of dough properties were less pronounced for integral wheat and for integral rye flour than for the wheat flour T-500. The addition of the additive caused the decreases of water absorption and the majority of the $C$-values $\left(C_{2}-C_{5}\right)$ for all investigated flours as well as the decrease of dough stability for white flour. With additions of the additive, the stability of dough obtained from integral flours increased. According to Ozturk et al. [46], the dough stability highly significantly correlates $(p<0.001)$ with some of the flour characteristics, such as protein content, the wet gluten content and sedimentation values, which can all be explained with changes in the structure of gluten. The stability is to the greatest degree determined by the interactions of polymer proteins through the creations of the disulphide $(-S-S-)$ bonds and disappearance of the hydrogen bonds [47]. It is affected by the combination of mechanical shear stress and temperature that induce decreases of the torque moment due to starting-up of protein destabilization and unwinding of their structure [33]. Integral wheat or rye flours showed better starting protein quality and lower level of protein network weakening degree than wheat flour. It was especially pronounced for the integral rye flour $\left(C_{2}, 0.5 \mathrm{Nm}\right)$. The changes that proteins had undergone during mixing and heating to $30{ }^{\circ} \mathrm{C}$ in this flour were the lowest. This was also confirmed by other investigation [48], which observed good behavior of proteins in samples of integral flours, i.e., their higher stability during heating phase, later starting of weakening and slower protein breakdown. Somewhat better quality of proteins in the integral flours was also con- 


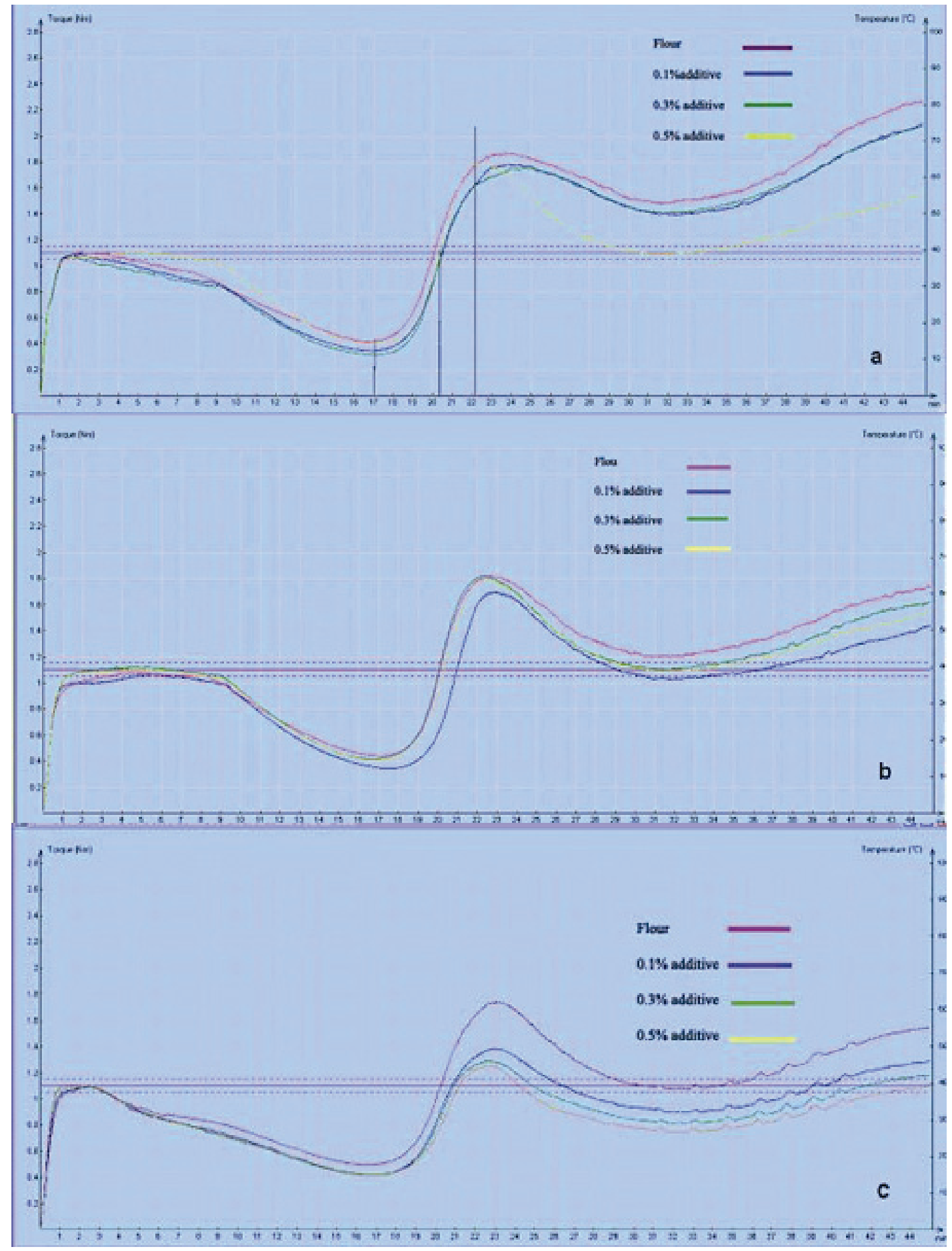

Figure 1. Effects of the addition of different amounts of additive to: a) wheat flour T-500; b) mixture of wheat flour and integral wheat flour (50:50); c) mixture of wheat flour and integral rye flour (40:60).

firmed by the lower differences of $C_{1}-C_{2}$ values when compared to those recorded for dough from the T-500 wheat flour [46].

The effect of starch, i.e., its gelatinization, gel formation and retrogradation, as well as the activities of enzymes could be observed later, with the increasing temperature [49] and it was reflected by the $C_{3}, C_{4}$ and $C_{5}$ values. The changes of these parameters were pro- nounced for all investigated samples, and they highly differed, depending on the type of flour. On the correlation of these Mixolab parameters with the quality of bakery products, and with several other factors, such as protein content and content of the damaged starch and sedimentation value indicated some other results [46]. Based on the highly significant correlation $(p<0.001)$ between $C_{3}$ and $C_{4}$ values measured in dough and 
greater pastry diameters and its spreading-out, these authors concluded that a good flour for pastry production is characterized by high values of $C_{3}$ and $C_{4}$ parameters (being 2.45 and $2.46 \mathrm{Nm}$ ), and that the insight into these parameters could provide good estimation of the baking quality of flour.

For the investigated flours the $C_{3}$ and $C_{4}$ values were not high, being 1.87 and $1.47 \mathrm{Nm}$ for wheat flour T-500; 1.82 and $1.20 \mathrm{Nm}$ for integral wheat flour; 1.74 and $1.07 \mathrm{Nm}$ for integral rye flour. Such behavior could be explained as the consequence of presence of high quantity of damaged starch granules because of their easier degradation, which is additionally stimulated by the enzymes present in the additive.

It was found [46] that the $C_{5}$ values show highly significant correlation $(p<0.01)$ only with the saccharified starch content, and that those values for flour samples that were characterized as having lower baking quality were within limits of $2.39,2.73$, up to $3.16 \mathrm{Nm}$. If compared with the $C_{5}$ values obtained for the flour samples tested in our experiment, they had increased saccharified starch contents, so their lower baking quality was to be expected. The lowest damage degree $\left(C_{5}\right.$ value
$2.28 \mathrm{Nm}$ ) and the best baking properties could be expected for the white flour; integral wheat flour showed somewhat higher damage degree $\left(C_{5}\right.$ value $1.75 \mathrm{Nm}$ ) and thus lower expected baking quality, and the highest damage degree $\left(C_{5}\right.$ value $\left.1.56 \mathrm{Nm}\right)$ was found for the integral rye flour, so it was characterized by the poorest baking quality.

With the increase of temperature during the investigations in the Mixolab, but also during baking, the starch in flour T-500 showed better performances. This is probably the consequence of competition for water between starch and bran, which represent a component in the integral flours. Good starch characteristics are a prerequisite for good shelf life of bread. It was possible to predict the bread behavior during its storage [15] so that the low stability of starch during heating could be linked with the increased shelf life.

\section{Sensory evaluation of different bread samples during their storage for up to 72 hours}

As can be seen in Figure 2a, the highest sensory scores for fresh breads were given to samples of wheat bread supplemented with $0.3 \%$ additive (very good

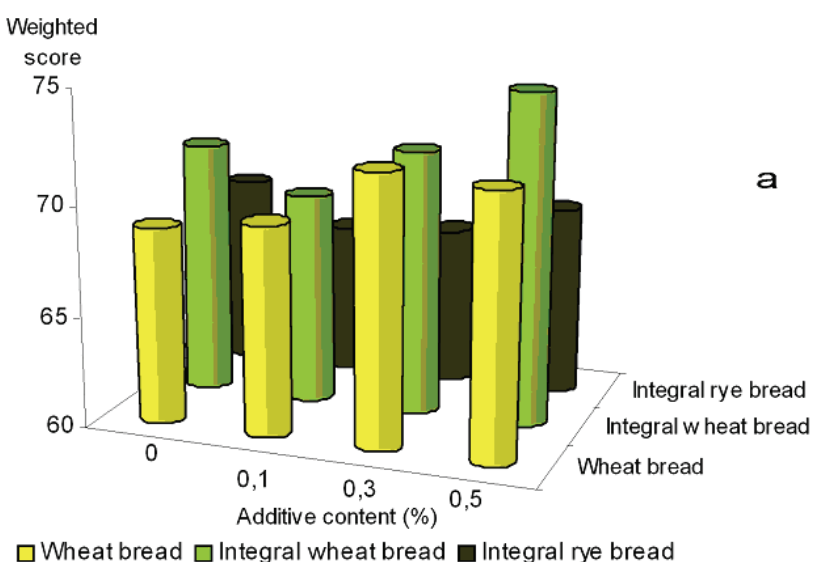

$\square$ Wheat bread $\square$ Integral wheat bread $\square$ Integral rye bread

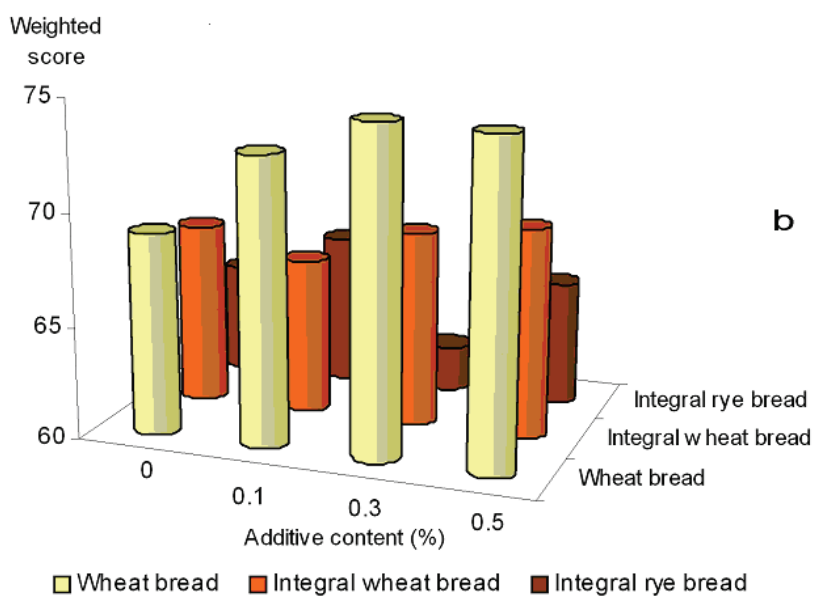

Figure 2. Sensory evaluation of different bread samples during their storage a) fresh breads and b) 3 days old breads. 
quality, 72.1 points), which had the largest volume $(6.81 \mathrm{ml} / \mathrm{g})$, very light and smooth pore of crumb, fine structure. Based on the scores assigned by panelists, the second ranked bread was the fresh wheat integral bread with the addition of $0.5 \%$ additive (very good quality, 74.85 points and volume of $3.89 \mathrm{ml} / \mathrm{g}$ ). The crumb of this bread was a little darker in color, had uniform structure and an intense aroma. The group of rye breads was rated the worst (good quality: with different concentration of additive 66.85 to 68.55 points). Generally, in this group, the higher concentration of additive caused a slight volume increase (7 to $12.5 \%$ ), slightly brighter crumb color, small and thick pores and less expressed aroma (neutral smell, less acid taste).

During the storage of $72 \mathrm{~h}$, the overall quality within the group of integral wheat and rye bread decreased due to changes in textural properties and loss of flavor and there was a slight decrease in volume. On the other hand, the overall quality of white bread was a somewhat better (except the volume whose value con- siderably decreased), with scores 74.5 to 72.8 points (Figure 2b).

According to the results of Levene's test of homogeneity of variances of data for all the evaluated sensory properties and the weighted mean score of the assessed product groups with different concentrations of additives, the variances were homogeneous, with the exception of those for the sensory property for appearance of wheat bread $(p<0.05)$ and the weighted mean score for integral rye bread. In these cases, the results should be accepted with a lower degree of certainty.

Based on the results of two-factorial analysis of variance for all three groups of bread it can be seen that the first observed factor, storage time, had a significant $(p<0.01)$ effect on the sensory property for aroma-taste of integral wheat bread, while on the weighted mean score for these breads storage time influenced with the lower level of significance $p<0.05$ (Figure 3 ). Other sensory characteristics of the exa-
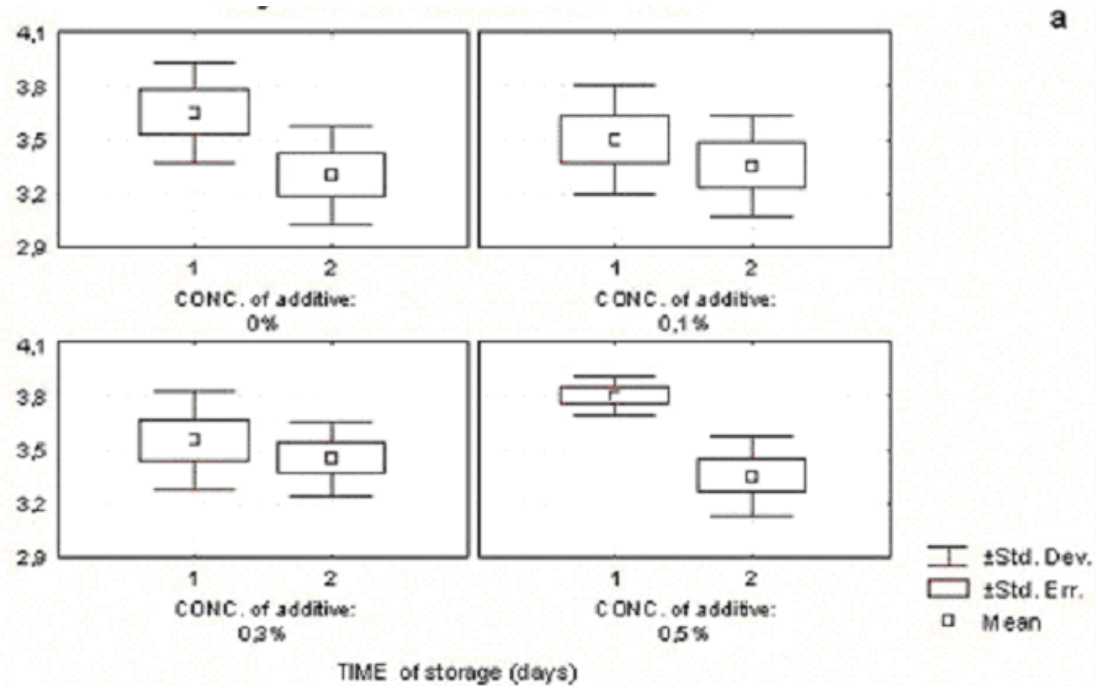

Mean

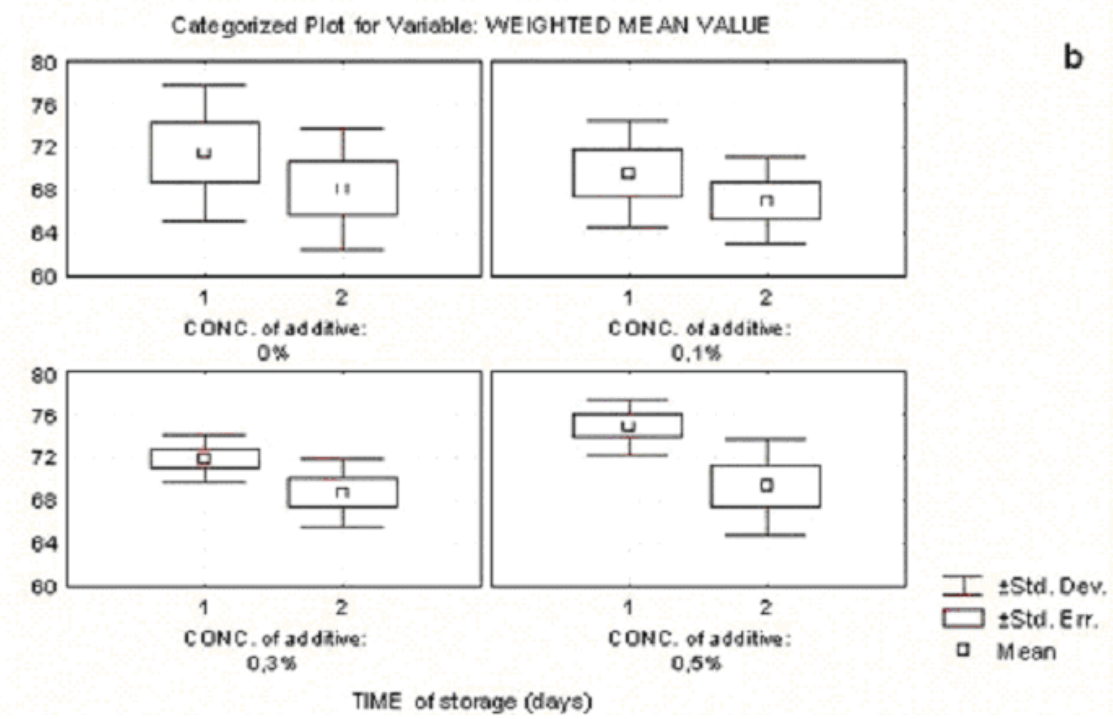

Figure 3. Box plots for bread sensory attribute a) aroma-taste and b) weighted mean score (integral wheat bread). 
mined breads did not significantly change during storage for $72 \mathrm{~h}$.

The concentration of additive, as a second investigated factor, had a significant effect on the sensory properties of wheat bread crumb texture $(p<0.05)$ (Figure 4) while other sensory properties of bread samples did not significantly change with the concentration of additives. The interaction of these two factors had no significant effect on any of the sensory properties of the investigated groups of bread. samples produced with concentrations of 0.1 and $0.5 \%$ of additive in the crumb texture, and in the group of integral rye bread between control and samples produced with the addition of $0.5 \%$ additive in terms of appearance.

\section{CONCLUSIONS}

Based on the results of estimation of the Mixolab parameters it can be concluded that the addition of the

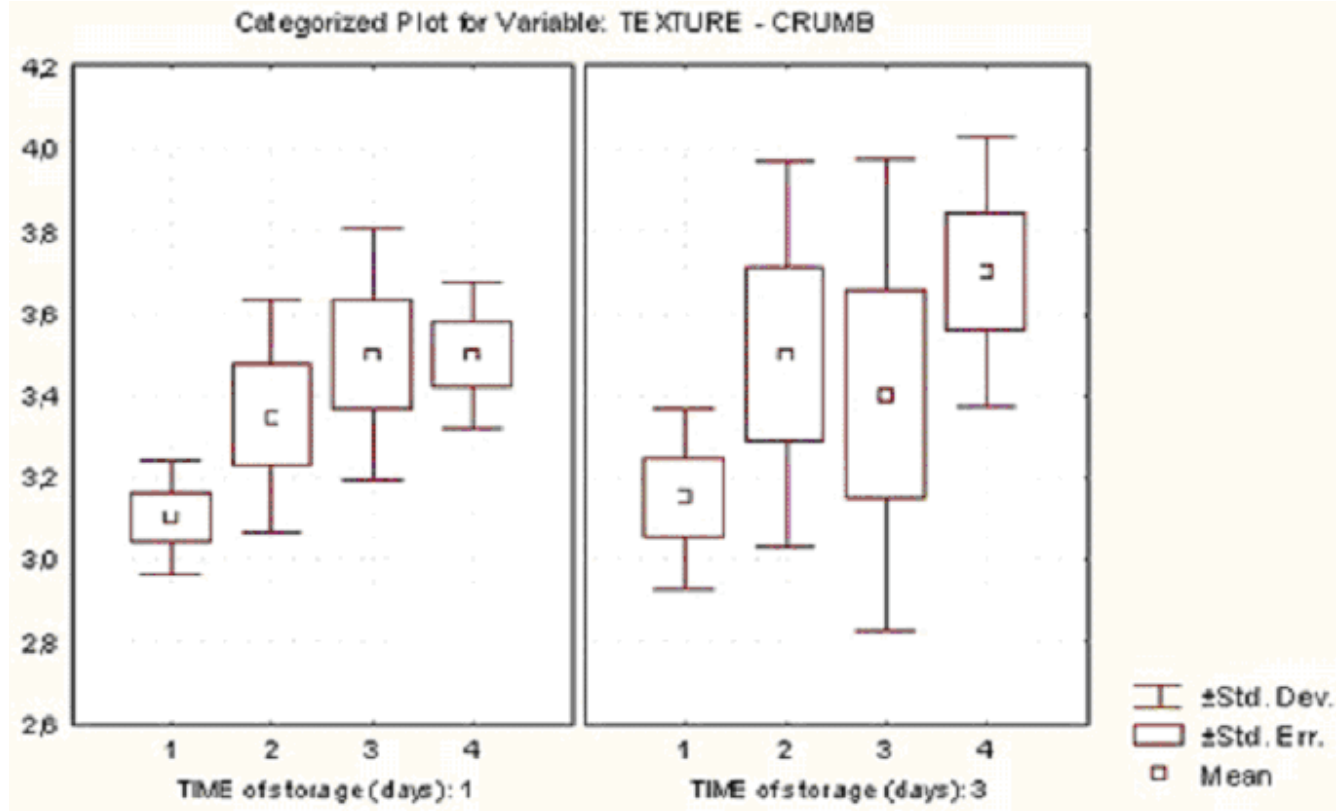

CONC. of additive

Figure 4. Box plots for bread sensory attribute texture-crumb (wheat bread).

The results of LSD test for all evaluated sensory attributes indicated that in the investigated groups of bread only the sensory property of flavor-taste of the integral rye bread changed significantly $(p<0.01)$ with the storage duration, along with its weighted mean score $(p<0.05)$.

In contrast, LSD test results suggested that the concentration of additive had a greater impact on sensory properties of the investigated bread samples. In the group of white bread samples, the most notable differences occured between the control samples $(0 \%)$ and those with 0.3 and $0.5 \%$ of additive. The sensory property of appearance was significantly changed ( $p<$ 0.05 ) between the control sample and the sample with $0.3 \%$ additive as well as the texture of crust and crumb and the weighted mean score. Likewise, significant differences $(p<0.05$ ) occurred between control samples and those with $0.5 \%$ additive in terms of texture of crust and weighted mean score, while the differences in terms of crumb texture were at even higher level of significance $(p<0.01)$. Significant differences were noticed in the group of integral wheat bread between additive induced the decrease of water absorption and of the majority of " $C$ " values in all types of flours. The best expected baking quality with the least damage of starch, which is one of the prerequisites for good shelf life of bread, was achieved with the wheat flour T-500, as it was confirmed only in this case by the increase of the weighted mean score. The weighted mean scores of integral wheat bread samples and integral rye bread samples decreased with the storage duration.

The addition of additive at a concentration of $0.3 \%$ had a major influence on the increase in volume, color and crumb texture of wheat bread. Concentration of $0.5 \%$ was the most effective in integral wheat bread. The application of additive in integral rye bread, regardless of the smaller increase in volume, caused a slight decrease in the overall quality compared to the control sample.

After $72 \mathrm{~h}$ of storage the quality of wheat bread was slightly enhanced, while in other groups there was a slight decrease in total quality. Based on the LSD test, it was concluded that a short term duration of storage had a significant impact $(p<0.01)$ on changes in aroma- 
taste of integral wheat bread and a significant effect $(p<0.05)$ on the weighted mean score of the same bread.

\section{Acknowledgements}

The authors would like to gratefully acknowledge Mrs. Mina Mitrović and the firm MC Labor for the provisional assignment of the Mixolab equipment and to specially thank Ms. Danijela Veljković and Mrs. Snežana Saljević who took a part in the experimental work.

\section{REFERENCES}

[1] O. Šimurina, J. Mastilović, Đ. Psodorov, B. Filipčev, The role of additives and additive blends to bakery industry, Wheat bread. 29 (2002) 105-116 (in Serbian).

[2] Statistical Office - Serbia and Montenegro (2004). Working Document, November 2004.

[3] T. Williams, G. Pullen, in: S.P. Cauvain, L.S. Young (Eds.), Functional ingradients: Technology of bread making, Springer, New York, 2007, pp. 51-91.

[4] O. Šimurina, J. Dozet, R. Vukobratović, The potential of domestic wheat harvest 1997 intended for specific purposes, Wheat bread 24 (1997) 189-195 (in Serbian).

[5] O. Šimurina, S. Bojat, B. Filipčev, Improving the quality of the puff pastry rolls from wheat of harvest 2001, Wheat bread 29 (2002) 1-8 (in Serbian).

[6] S. Bojat, O. Šimurina, B. Filipčev, Opportunities to improve the quality of bread from wheat harvest 2001, Wheat bread. 28 (2001) 131-140 (in Serbian).

[7] S. Bojat, J. Dozet, A. Petrović, Influence Sava lux-pecivit at the quality and freshness preservation pastry, Wheat bread. 22 (1995) 8-13 (in Serbian).

[8] S. Bojat, R. Vukobratović, O. Gajić, Lecithin powder as an emulsifier in bread and pastry production, Wheat bread. 24 (1997) 81-89 (in Serbian).

[9] J. Dozet, N. Toth, S. Jovanov, S. Eremić, O. Gajić, Dijamix HP 01 new powdery additive in bread and pastry production, Wheat bread. 23 (1996) 113-122 (in Serbian).

[10] A.H. Bloksma, W. Bushuk, in: Y. Pomeranz (Ed.), Rheology and chemistry of dough. Wheat: chemistry and technology, AACC, St Paul, 1988, pp. 131-218.

[11] B.S. Khatkar, D.J. Schofield, Dynamic rheology of wheat flour dough. II Assessment of dough strength and breadmaking quality, J. Sci. Food. Agr. 82 (2002) 823-826.

[12] J.M. Álava, S.S. Sahi, J. Garcia-Álvarez, A. Turó, J.A. Chávez, M.J. Garcia, J. Salazar, Use of ultrasound for the determination of flour quality, Ultrasonics 46 (2007) 270-276.

[13] P. Fustier, F. Castaigne, S.L. Turgeon, C.G. Biliaderis, Flour constituent interactions and their influence on the dough rheology and quality of semi-sweet biscuits: A mixture design approach with reconstituted blends of gluten, water-solubles and starch fractions, J. Cereal. Sci. 48 (2008) 144-158.

[14] T. Dapčević, M. Hadnađev, M. Pojić, Evaluation of the possibility to Replace conventional rheological wheat flour quality control instruments with the new measure- ment tool-Mixolab, Agric. Conspec. Sci. 74 (2009)169-174 .

[15] C. Collar, Significance of viscosity profile of pasted and gelled formulated wheat dough on bread staling, Eur. Food Res. Technol. 216 (2003) 505-513.

[16] C. Collar, E. Armero, Physico-chemical mechanisms of bread staling during storage: Formulated dough as a technological issue for improvement of bread functionnality and keeping quality, Recent Res. Develop. Nutrition 1(1996) 115-143.

[17] D. Beleslin, Starch retrogradation and other changes during bread staling, depending on the test of amyloIytic activities, Ph.D. Thesis, Faculty of Technology, Novi Sad, (1973) (in Serbian).

[18] J.A. Gray, J.N. Bemiller Bread, Staling: Molecular Basis and Control, Compr. Rev. Food Sci., F 2 (2003) 1-21.

[19] C.S. Setser, in: R.E. Hebeda, H. Zobel (Eds.), Sensory methods: Baked goods freshness, Macel Dekker, New York, 1996, pp. 171-187.

[20] B. Škrbić, B. Filipčev, Nutritional and sensory evaluation of wheat breads supplemented with oleic-rich sunflower seed, Food Chem. 108 (2008) 119-129.

[21] E.F. See, N. Wan, W.A. Noor, A.A. Aziah, Physico-Chemical and Sensory Evaluation of Breads Supplemented with Pumpkin Flour, ASEAN Food J. 14 (2007) 123-130.

[22] A. Hamad, M. Fields, Nutritional and Sensory Evaluation of Bread Made from Fermented wheat Meal and Corn Chips Made from Fermented Corn, Meal. J. Food Sci. 44 (2006) 1514-1516.

[23] V. Gattàs, E. Hiche, D.E. Ballester, Yàñez Sensory evaluation of bread with potato flour, Arch. Latinoam. Nutr. 33 (1983) 56-66.

[24] U. Stöllman, B. Lundgren, Texture changes in white bread: Effects of processing and storage, Cereal Chem. 64 (1987) 230-236.

[25] L. Slade, H. Levine, in: S.S. Stivala, V. Crescenzi, I.C.M. Dea, (Eds.), Recent Advances in Starch Retrogradation: Industrial Polysaccharides-The Impact of Biotechnology and Advanced Methodologies, Gordon and Breach, New York, 1987, pp. 387-430.

[26] K. Galić, D. Ćurić, D. Gabrić, Shelf life of packed bakery goods, Crit. Rev. Food Sci. 49 (2009) 405-426.

[27] E.M.A. Willhoft, Mechanism and theory of staling of bread and baked goods and associated changes in textural properties, J. Texture Stud. 4 (1973) 292-322.

[28] P.L. Brady, S.M. Mayer, Correlation of sensory and instrumental measurements of bread texture, Cereal Chem. 62 (1985) 70-72.

[29] K. Lorenz, J. Maga, Staling of white bread: changes in carbonyl composition and GLC headspace profiles, J. Agr. Food Chem. 20 (1972) 211-213.

[30] ICC (1996a) ICC Standard Method No. 110/1: Determination of Moisture Content of Cereals and Cereal Products (Practical Method), International Association for Cereal Chemistry, Wienna, Austria.

[31] ICC (1996b). ICC Standard Method No. 104/1: Determination of Ash in Cereals and Cereal Products. Wienna Austria: International Association for Cereal Chemistry. 
[32] ICC (1996c) ICC Standard Method No. 105/1: Determination of Crude Protein in Cereals and Cereal Products for Food and Feed, International Association for Cereal Chemistry, Wienna, Austria.

[33] C.M. Rosell, C. Collar, M. Haros, Assessment of hydrocolloid effects on the thermo-mechanical properties of wheat using the Mixolab, Food Hydrocolloid. 21 (2007) 452-462.

[34] Chopin Applications Laboratory Mixolab Applications Handbook-Rheological and Enzymatic Analysis, Manual d'applications Mixolab, Chopin Technologies, France, 2009.

[35] ISO 8589 (1988), Sensory analysis - General guidance for the design of test rooms.

[36] ISO 5492 (1992), Sensory analysis - Vocabulary.

[37] ISO 8586-1 (1993), Sensory analysis - General guidance for the selection training and monitoring of assessors Part 1: Selected assessors.

[38] ISO 8586-2 (1994a), Sensory analysis - General guidance for the selection training and monitoring of assessors Part 2: Experts.

[39] ISO 11036 (1994b), Sensory analysis - Methodology Texture profile.

[40] J. Joksimović, Fundamentals of control and quality management in food production, Economic Review, Belgrade, Serbia, 1977 (in Serbian).
[41] S. Hadživuković Statistical methods. University of Belgrade, Faculty of Agriculture, Belgrade, Serbia, 1991 (in Serbian).

[42] M. Lovrić, Method of the Nonparametric Statistical Conclusion, University of Belgrade Faculty of Economics. Belgrade, Serbia, 2002. (in Serbian).

[43] B.J. Dobrasycyzk, M.P. Morgenstern, Rheology and bread making process, J. Cereal Sci. 38 (2003) 229-245.

[44] C. Collar, E. Santos, C.M. Rosell, Significance of dietary fiber on the viscometric pattern of pasted and gelled flour-fiber blends, Cereal Chem. 83 (2006) 370-376.

[45] C. Collar, C. Bollain, Relationships between dough functional indicators during bread making steps in formulated sample, Eur. Food Res. Technol. 220 (2005) 372-379 .

[46] S. Ozturk, K. Kahraman, B. Tiftik, H. Koksel, Predicting the cookie quality of flours by using Mixolab, Eur. Food Res. Technol. 227 (2008) 1549-1554.

[47] T. Aussenac, J.L. Carceller, D. Kleiber, Changes in SDS solubility of glutenin polymers during dough mixing and resting, Cereal Chem. 78 (2001) 39-45.

[48] C. Collar, C. Bollain, C.M. Rosell, Rheological Behavior of Formulated Bread Dough during Mixing and Heating, Food Sci. Technol. Int. 13 (2007) 99-107.

[49] E. Chiotelli, A. Rolle, M. Le Meste, Rheological properties of soft wheat flour dough: effect of salt and triglycerides, Cereal Chem. 81 (2004) 459-468.

\section{IZVOD}

\section{TERMO-MEHANIČKA I SENZORNA SVOJSTVA PŠENIČNOG I RAŽANOG HLEBA PRIPREMLJENIH SA RAZLIČITIM KONCENTRACIJAMA ADITIVA}

Mirjana A. Demin ${ }^{1}$, Jovanka V. Popov-Raljić ${ }^{1}$, Jovanka G. Laličćć-Petronijević ${ }^{1}$, Biljana B. Rabrenović ${ }^{1}$, Bojana V. Filipčev ${ }^{2}$, Olivera D. Šimurina ${ }^{2}$

${ }^{1}$ Univerzitet u Beogradu, Poljoprivredni fakultet, Beograd, Srbija

${ }^{2}$ Univerzitet u Novi Sad, Institut za prehrambene tehnologije, Novi Sad, Srbija

(Naučni rad)

Primenom klasičnih reoloških metoda moguće je ispitati kvalitet brašna i njegovu pogodnost za specifične namene, uglavnom na bazi osobina proteina $i$ skorba. Upotrebom savremenih uređaja simuliraju se procesi koji se odvijaju tokom proizvodnje hleba i dobija se niz informacija o fizičkim parametrima testa (apsorpcija vode, razvoj i stabilnost testa, mehanička i termička razgradnja proteinske mreže), stanju skroba u testu (nivo želatinizacije, amilolitička aktivnost, stabilnost pri kuvanju) uz značajno skraćen postupka ispitivanja. U ovom radu, ispitivani su efekti različitih koncentracija kombinovanog aditiva na reološka svojstva testa i senzorne osobine tri grupe hleba. Najbolji početni kvalitet i najniži stepen slabljenja proteinske mreže je uočen kod testa dobijenog iz mešavine pšeničnog i ražanog brašna. Najbolja očekivana pecivna svojstva imalo je belo pšenično brašno, zbog najmanjeg oštećenja skroba. Upotreba aditiva uticala je na apsorpciju vode i na većinu C-vrednosti svih vrsta brašna. Koncentracija aditiva imala je značajan uticaj na senzorno svojstvo teksture, tj, mrvljivost pšeničnog hleba. Vreme skladištenja je veoma značajno $(p<0,01)$ uticalo na senzorna svojstava arome tj. ukusa integralnog pšeničnog hleba i statistički značajano na ponderisanu srednju vrednost ocene ovog hleba. Interakcija ova dva faktora nema statistički značajan uticaj na bilo koje od senzornih svojstava ispitivanih grupa hleba.

Ključne reči: Pšenični i ražani hleb • Aditiv • Mixolab • Senzorna svojstva 